\title{
Investigating banks' financial structure on profitability and price volatility of banks' shares: Evidence from Tehran Stock Exchange
}

\author{
Zeinab Mirzaei $^{\mathrm{a}^{*}}$, Mohsen Hamidian ${ }^{\mathrm{b}}$ and Mohammad Khodaei Valahzaghard ${ }^{\mathrm{c}}$
}

${ }^{a}$ M.Sc. Student, Department of Commercial Management, School of Management and Human Sciences, Tehran North Branch, Islamic Azad University (IAU), Tehran, Iran

${ }^{b}$ Assist. Prof. \& Faculty Member, Department of Accounting, School of Management and Accounting, South Tehran Branch, Islamic Azad University (IAU), Tehran, Iran

${ }^{c}$ Assist. Prof. \& Faculty Member, Department of Accounting, School of Management and Human Sciences, Tehran North Branch, Islamic Azad University (IAU), Tehran, Iran

CHRON I C LE

Article history:

Received March 24, 2014

Accepted 20 September 2014

Available online

September 242014

Debt ratio

Profitability

Stock price volatility

Shareholders' equity ratio

\begin{abstract}
A B S T R A C T
This paper presents an empirical investigation to study the relationship between financial structure on profitability and price volatility of banks' shares, which are operating in Iran. The proposed study considers the information of 21 Iranian banks over the period 2006-2012. Using some regression techniques, the study has determined that there was a negative relationship between leverage and return on assets but there was not any meaningful relationship between leverage and price volatility when the level of significance is five percent. In addition, the study has determined that there was a positive relationship between equity ratio and return on assets and there was a positive relationship between equity ratio and price volatility when the level of significance was five percent.
\end{abstract}

\section{Introduction}

During the past few years, there have been tremendous efforts on learning more about the factors influencing on banking industry (Boyd \& De Nicolo, 2005; Padilla \& Pagano, 2000; Rice \& Strahan, 2010). Barth et al. (2014), for instance, applied new database on bank regulation and supervision in 107 countries to evaluate the relationship between specific regulatory and supervisory practices and banking-sector development, efficiency, and fragility. Beck et al. (2010) determined the winners and losers from bank deregulation in the United States in a comprehensive study. Beck et al. (2013) investigated the banks' stability among some US banks. Berger et al. (2009) studied the bank competition and financial stability in some US banks. Boyd and Runkle (1993) investigated the relationship between bank size and profitability in banking industry. Banking industry is always influenced by regulations in most countries around the world (Marcus, 1984). Carletti and Vives (2007) presented a comprehensive study on regulation and competition policy in the banking sector. Claessens and Laeven (2004) tried to determine important drivers on increasing competition in banking industry.

*Corresponding author.

E-mail addresses: zeinab_mirzaei67@yahoo.com (Z. Mirzaei)

C) 2014 Growing Science Ltd. All rights reserved. doi: $10.5267 /$ j.ms 1.2014.9.014 
Dick and Lehnert (2010) tried to find the effects of personal bankruptcy and its relationship with credit market competition. Filosa (2007) performed a stress testing of the stability of the Italian banking system using VAR technique. Houston et al. (2010) reported that stronger creditor rights tend to promote greater bank risk taking. Kallberg and Udell (2003) investigated the value of private sector business credit information sharing in US banking sector.

Pagano and Jappelli (1993) presented a model with adverse selection where information sharing between lenders arises endogenously. In their model, lenders' incentives to share data about borrowers were positively associated with the mobility and heterogeneity of borrowers, to the size of the credit market, and to advances in information technology. In addition, information sharing was believed to increase the volume of lending when adverse selection becomes severe that safe borrowers drop out of the market. According to Pereira and Zhang (2010), stock returns decrease with an increase in the volatility of liquidity.

Rajan and Zingales (1995) studied the determinants of capital structure choice by analyzing the financing decisions of public companies in the major industrialized countries. They reported that factors detected by previous studies as correlated in the cross-section with firm leverage in the United States, were correlated in other countries as well. Roden and Lewellen (1995) investigated the composition of the financing packages applied in a large sample of leveraged buyout transactions in order to test a set of hypotheses developed in the prior literature about the determinants of corporate capital structure decisions. They concentrated in the role of agency costs, bankruptcy risks, and tax considerations. They reported some evidence that all three had an effect, both on the degree of leverage employed in the transactions and on the attributes of the borrowings undertaken.

Tan et al. (2007) investigated the association between the intellectual capital (IC) of companies and their financial performance. They reported that IC and company performance were positively related; IC was correlated to future company performance; the rate of growth of a company's IC was positively associated with the company's performance. Turk Ariss (2010) studied how various degrees of market power affect bank efficiency and stability in the context of developing economies. It gave some insight on the competition-stability nexus by documenting and investigating the complex interactions between a tripod of variables that are central for regulators. They reported that an increase in the degree of market power leads to bigger bank stability and enhanced profit efficiency, despite significant cost efficiency losses.

\section{The proposed study}

The proposed study considers whether bank's structure could influence on profitability of banks as well as stock price or not. Therefore, there are two main hypotheses associated with the proposed study of this paper as follows,

1. There is a relationship between bank's structure and profitability of banks.

2. There is a relationship between bank's structure and banks' stock prices.

The proposed study also considers the following three sub-hypotheses,

1. There is a relationship between banks' profitability and debt ratio.

2. There is a relationship between banks' stock prices and debt ratio.

3. There is a relationship between banks' profitability and equity ratio.

4. There is a relationship between banks' stock prices and equity ratio. 
The proposed study of this paper uses the models developed by Yeh et al. (2013) as follows,

$$
\begin{aligned}
& R O A_{i, t}=\alpha_{0}+\beta_{1} L E V_{i, t}+\beta_{2} \text { GroVol }_{i, t}+\beta_{3} \text { SSAct }_{i, t}+\beta_{4} E_{f f} f_{i, t}+\beta_{5} \operatorname{CapExp}_{i, t}+\beta_{6} \operatorname{Tra}_{i, t}+\beta_{7} \operatorname{Size}+\varepsilon_{\mathrm{i}, \mathrm{t}} \\
& \Delta G P_{i, t}=\alpha_{0}+\beta_{1} L E V_{i, t}+\beta_{2} \operatorname{GroVol}_{i, t}+\beta_{3} \operatorname{FSAct}_{i, t}+\beta_{4} E_{f f}+\beta_{5} \operatorname{CapExp}_{i, t}+\beta_{6} \operatorname{Tra}_{i, t}+\beta_{7} \operatorname{Size}_{\mathrm{i}_{\mathrm{i}, \mathrm{t}}} \\
& R O A_{i, t}=\alpha_{0}+\beta_{1} E u_{i, t}+\beta_{2} \operatorname{GroVol}_{i, t}+\beta_{3} \operatorname{FSAct}_{i, t}+\beta_{4} \operatorname{Eff}_{i, t}+\beta_{5} \operatorname{CapExp}_{i, t}+\beta_{6} \operatorname{Tra}_{i, t}+\beta_{7} \operatorname{Size}+\varepsilon_{\mathrm{i}, t} \\
& \Delta G P_{i, t}=\alpha_{0}+\beta_{1} E u_{i, t}+\beta_{2} \operatorname{GroVol}_{i, t}+\beta_{3} \text { SSAct }_{i, t}+\beta_{4} \operatorname{Eff}_{i, t}+\beta_{5} \operatorname{CapExp}_{i, t}+\beta_{6} \operatorname{Tra}_{i, t}+\beta_{7} \operatorname{Size}_{\varepsilon_{\mathrm{i}, \mathrm{t}}}
\end{aligned}
$$

where $R_{0 A} A_{i, t}, \triangle G P_{i t}, L E V_{i, t}$, GroVol $_{i, t}, F_{S A c t}, F_{i, t}$, CapExp $_{i, t}, \operatorname{Tra}_{i, t}$ and Size are return on assets, volatility of stock price, leverage ratio, volatility of stock return, investing activities, efficiency, capital expenditure, volume of financial activities and size of firm $i$ at time $t$, respectively. The proposed study considers the information of 21 Iranian banks over the period 2006-2012 (Kothari, 2004). Table 1 shows details of the results of our survey.

Table 1

The results of some basic statistics

\begin{tabular}{lccccccc}
\hline \multicolumn{1}{c}{ Variable } & $\mathrm{N}$ & mean & Standard deviation & Min & Max & Skewness & Kurtosis \\
\hline Profitability & 147 & 0.2992 & 0.449 & -0.0461 & 2.2181 & 2.594 & 6.5 \\
Stock volatility & 147 & 0.1758 & 0.7239 & -0.9751 & 2.7653 & 1.691 & 3.262 \\
Debt ratio & 147 & 0.5412 & 0.2736 & 0.0408 & 1.7265 & 0.532 & 1.627 \\
Equity ratio & 147 & 0.7356 & 0.0569 & 0.5868 & 0.8516 & 0.038 & -0.333 \\
Stock price & 147 & -0.0209 & 0.7175 & -1.8068 & 3.0124 & 0.465 & 1.98 \\
Investment & 147 & 0.8843 & 0.3208 & 0 & 1 & -2.429 & 3.951 \\
Efficiency & 147 & 0.9171 & 0.4689 & -2.2274 & 2.2736 & -2.432 & 15.489 \\
Capital expenditure & 147 & 0.0987 & 0.4101 & -1.951 & 0.9978 & -1.923 & 9.721 \\
Financial activities & 147 & 0.0516 & 0.2134 & 0.0003 & 2.5972 & 11.774 & 141.279 \\
Bank size & 147 & 0.7742 & 0.0538 & 0.6801 & 0.9035 & 0.487 & -0.438 \\
\hline
\end{tabular}

The preliminary results of Table 1, indicate that the data were normally distributed. In addition, Table 2 shows details of the implementation of Kolmogorov-Smirnov test. Based on the results of Table 2, profitability and price volatility are normally distributed. We have also considered the correlation among different independent variables and have not found significant correlations.

Table 2

The results of Kolmogorov-Smirnov test

\begin{tabular}{lccc}
\hline Variable & Number & KS & Sig. \\
\hline Profitability & 147 & 0.637 & 0.809 \\
Price volatility & 147 & 0.451 & 0.987 \\
\hline
\end{tabular}

\section{The results}

In this section, we present details of the implementation of regression analysis on Eq. (1) to Eq. (4).

\subsection{The relationship between debt and profitability}

The first hypothesis of this survey investigates the relationship between debt and profitability. Table 3 demonstrates the results of Chaw and Huasman. Based on the results of Table 3 we may use Panel data with fixed effect. Table 4 shows details of other necessary statistics. 
Table 3

The summary of Chaw and Huasman tests

\begin{tabular}{lccccc}
\hline Test & Number & Statistics & Statistics value & Degree of freedom & Sig. \\
\hline Chaw & 147 & $\mathrm{~F}$ & 2.2360 & $(20,119)$ & 0.0040 \\
Hausman & 147 & Chi-Square & 5.6860 & 7 & 0.0168 \\
\hline
\end{tabular}

Table 4

The results of some statistics

\begin{tabular}{ccccccc}
\hline \multicolumn{2}{c}{ Jarque-Bera } & \multicolumn{2}{c}{ Breusch-Pagan } & Durbin-Watson & \multicolumn{2}{c}{ Ramsey } \\
\hline Chi-Square & P-value & F & P-value & D & F & P-value \\
\hline 1.8407 & 0.7541 & 1.5532 & 0.0244 & 2.23 & 0.1814 & 0.8343 \\
\hline
\end{tabular}

As we can observe from the results of Table 4, all statistics are within the acceptable level and we may examine the first hypothesis based on the regression technique as follows,

$$
\begin{aligned}
& R O A_{i, t}=-2.8988-0.1140 \mathrm{LEV}_{i, t}+0.0626 \mathrm{GroVol}_{i, t}+0.0225 \mathrm{FSAct}_{i, t}+0.0241 \mathrm{Eff}_{i, t}+0.0568 \mathrm{CapExp}_{i, t}+0.0973 \text { Tra }_{i, t}+4.1438 \text { Size }+\varepsilon_{\mathrm{i}, t} \\
& \begin{array}{llllllll}
\text { t-value } & -5.1907 & -2.1465 & 2.5685 & 0.3626 & 0.7072 & 0.9929 & 1.1245
\end{array}
\end{aligned}
$$

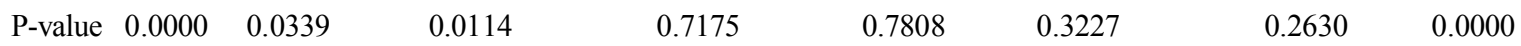

F-value $=5.3514$ P-value $=0.0000 \mathrm{R}^{2}=0.5483$

As we can observe from the results of regression analysis, F-value is statistically significant and RSquare value is equal to 0.5483 , which means the independent variables can predict approximately $55 \%$ of the changes of dependent variable. The sign of Leverage is $\beta=-2.1465$ with t-value $=-2.1465$ and $\mathrm{P}$-value $=0.0339$. Therefore, we can conclude that there was a negative relationship between leverage and return on assets when the level of significance is five percent and the first hypothesis of the survey is confirmed.

\subsection{The relationship between price volatility and profitability}

The second hypothesis of this survey investigates the relationship between price volatality and profitability. Table 5 shows the results of Chaw and Huasman.

\section{Table 5}

The summary of Chaw and Huasman tests

\begin{tabular}{lccccc}
\hline Test & Number & Statistics & Statistics value & Degree of freedom & Sig. \\
\hline Chaw & 147 & $\mathrm{~F}$ & 1.2380 & $(20,119)$ & 0.0361 \\
Hausman & 147 & Chi-Square & 4.0770 & 7 & 0.0209 \\
\hline
\end{tabular}

Based on the results of Table 5 we may use Panel data with fixed effect. Table 4 shows details of other necessary statistics.

Table 6

The results of some statistics

\begin{tabular}{ccccccc}
\hline \multicolumn{2}{c}{ Jarque-Bera } & \multicolumn{2}{c}{ Breusch-Pagan } & Durbin-Watson & \multicolumn{2}{c}{ Ramsey } \\
\hline Chi-Square & P-value & F & P-value & D & F & P-value \\
\hline 1.6289 & 0.3430 & 1.3412 & 0.0004 & 2.29 & 2.3838 & 0.0960 \\
\hline
\end{tabular}

As we can observe from the results of Table 6, all statistics are within the acceptable level and we may examine the second hypothesis based on the regression technique as follows,

$$
\begin{aligned}
& \Delta G P_{i, t}=-0.7011-0.1545 \text { LEV }_{i, t}-0.1524 \text { GroVol }_{i, t}+0.1209 \text { FSAct }_{i, t}+0.0272 \text { Eff }_{i, t}+0.0356 \text { CapExp }_{i, t}+0.055 \text { Tra }_{i, t}+1.0613 \text { Size }+\varepsilon_{\mathrm{i}, \mathrm{t}} \\
& \begin{array}{llllllll}
\mathrm{t} \text {-value }-0.8940 & -0.6672 & -2.0507 & 0.62006 & 0.2269 & 0.2487 & 0.0216 & 1.1306
\end{array} \\
& \begin{array}{llllllll}
\text { P-value } & 0.3731 & 0.5059 & 0.0425 & 0.5364 & 0.8208 & 0.8040 & 0.9827
\end{array}
\end{aligned}
$$


As we can observe from the results of regression analysis, F-value is statistically significant and RSquare value is equal to 0.5053 , which means the independent variables can predict approximately $51 \%$ of the changes of dependent variable. The sign of Leverage is $\beta=-0.1545$ with t-value $=-0.6672$ and P-value $=0.5059$. Therefore, we can conclude that there was not any meaningful relationship between leverage and price volatility when the level of significance is five percent and the second hypothesis of the survey was not confirmed.

\subsection{The relationship between equity ratio and profitability}

The third hypothesis of this survey investigates the relationship between equity and profitability. Table 7 shows the results of Chaw and Huasman.

Table 7

The summary of Chaw and Huasman tests

\begin{tabular}{lccccc}
\hline Test & Number & Statistics & Statistics value & Degree of freedom & Sig. \\
\hline Chaw & 147 & F & 1.9919 & $(20,119)$ & 0.0122 \\
Hausman & 147 & Chi-Square & 15.5260 & 7 & 0.0298 \\
\hline
\end{tabular}

Based on the results of Table 7 we may use Panel data with fixed effect. Table 8 presents details of other necessary statistics.

Table 8

The results of some statistics

\begin{tabular}{ccccccc}
\hline \multicolumn{2}{c}{ Jarque-Bera } & \multicolumn{2}{c}{ Breusch-Pagan } & \multicolumn{2}{c}{ Durbin-Watson } & \multicolumn{2}{c}{ Ramsey } \\
\hline Chi-Square & P-value & F & P-value & D & F & P-value \\
\hline 1.3159 & 0.2254 & 1.3439 & 0.0342 & 2.23 & 0.6599 & 0.5185 \\
\hline
\end{tabular}

As we can observe from the results of Table 8, all statistics are within the acceptable level and we may examine the first hypothesis based on the regression technique as follows,

$$
\begin{aligned}
& R O A_{i, t}=-2.4195+1.9179 E_{q u} u_{i, t}+0.0492 \text { GroVol }_{i, t}+0.0435 \text { FSAct }_{i, t}+0.0248 \text { Eff }_{i, t}+0.1166 \text { CapExp }_{i, t}+0.1522 \text { Tra }_{i, t}+1.5863 \text { Size }+\varepsilon_{\mathrm{i}, t} \\
& \begin{array}{llllllll}
\text { t-value } & -4.8023 & 1.5742 & 2.0937 & 0.7344 & 0.7431 & 2.0220 & 1.7742
\end{array} \\
& \begin{array}{llllllll}
\text { P-value } & 0.0000 & 0.0181 & 0.0436 & 0.4641 & 0.4588 & 0.0454 & 0.0786
\end{array}
\end{aligned}
$$

F-value $=4.3349 \mathrm{P}$-value $=0.0000 \mathrm{R}^{2}=0.4958$

As we can observe from the results of regression analysis, F-value is statistically significant and RSquare value is equal to 0.4958 , which means the independent variables can predict approximately $50 \%$ of the changes of dependent variable. The sign of Leverage is $\beta=1.9179$ with $t$-value $=1.5742$ and P-value $=0.0181$. Therefore, we can conclude that there was a positive relationship between equity ratio and return on assets when the level of significance is five percent and the third hypothesis of the survey is confirmed.

\subsection{The relationship between equity ratio and price volatility}

The fourth hypothesis of this survey investigates the relationship between equity ratio and price volatility. Table 9 presents the results of Chaw and Huasman.

\section{Table 9}

The summary of Chaw and Huasman tests

\begin{tabular}{lccccc}
\hline Test & Number & Statistics & Statistics value & Degree of freedom & Sig. \\
\hline Chaw & 147 & $\mathrm{~F}$ & 1.1535 & $(20,119)$ & 0.0070 \\
Hausman & 147 & Chi-Square & 3.9438 & 7 & 0.0062 \\
\hline
\end{tabular}


Based on the results of Table 9 we may use Panel data with fixed effect. Table 10 presents details of other necessary statistics.

Table 10

The results of some statistics

\begin{tabular}{ccccccc}
\hline \multicolumn{2}{c}{ Jarque-Bera } & \multicolumn{2}{c}{ Breusch-Pagan } & Durbin-Watson & \multicolumn{2}{c}{ Ramsey } \\
\hline Chi-Square & P-value & F & P-value & D & F & P-value \\
\hline 5.3040 & 0.0705 & 1.3180 & 0.0461 & 2.31 & 2.9648 & 0.0549 \\
\hline
\end{tabular}

As we can observe from the results of Table 10, all statistics are within the acceptable level and we may examine the first hypothesis based on the regression technique as follows,

\begin{tabular}{|c|c|c|c|c|c|c|c|}
\hline t-value 1.4522 & 1.5750 & -1.5834 & -0.1030 & 1.1748 & 0.9670 & 0.2483 & -0.4457 \\
\hline P-value 1.1491 & 0.0063 & 0.1160 & 0.9181 & 0.2424 & 0.3355 & 0.8043 & 0.6566 \\
\hline
\end{tabular}

F-vlaue $=1.1089 \mathrm{P}$-value $=0.0000 \mathrm{R}^{2}=0.3310$

As we can observe from the results of regression analysis, F-value is statistically significant and RSquare value is equal to 1.1089 , which means the independent variables can predict approximately $33 \%$ of the changes of dependent variable. The sign of leverage is $\beta=1.8748$ with t-value $=1.5750$ and P-value $=0.0063$. Therefore, we can conclude that there was a positive relationship between equity ratio and price volatility when the level of significance is five percent and the fourth hypothesis of the survey is confirmed.

\section{Conclusion}

In this paper, we have presented an empirical investigation to study the relationship between financial structure on profitability and price volatility of banks' shares, which were operating in Iran. The proposed study considered the information of 21 Iranian banks over the period 2006-2012. Using some regression techniques, the study has determined that there was a negative relationship between leverage and return on assets but there was not any meaningful relationship between leverage and price volatility when the level of significance is five percent. In addition, the study has determined that there was a positive relationship between equity ratio and return on assets and there was a positive relationship between equity ratio and price volatility when the level of significance was five percent. The results of the survey are consistent with findings of Abor (2005), Cetorelli and Gambera (2001), Gan (2004), Niresh (2012), Niresh (2012) and Pereira and Zhang (2010).

\section{Acknowledgement}

The authors would like to thank the anonymous referees for constructive comments on earlier version of this paper.

\section{References}

Abor, J. (2005). The effect of capital structure on profitability: an empirical analysis of listed firms in Ghana. The Journal of Risk Finance, 6(5), 438-445.

Barth, J. R., Caprio Jr, G., \& Levine, R. (2004). Bank regulation and supervision: what works best?. Journal of Financial intermediation, 13(2), 205-248.

Beck, T., Levine, R., \& Levkov, A. (2010). Big bad banks? The winners and losers from bank deregulation in the United States. The Journal of Finance,65(5), 1637-1667.

Beck, T., De Jonghe, O., \& Schepens, G. (2013). Bank competition and stability: cross-country heterogeneity. Journal of Financial Intermediation, 22(2), 218-244.

Berger, A. N., Klapper, L. F., \& Turk-Ariss, R. (2009). Bank competition and financial stability. Journal of Financial Services Research, 35(2), 99-118. 
Boyd, J. H., \& Runkle, D. E. (1993). Size and performance of banking firms: Testing the predictions of theory. Journal of Monetary Economics, 31(1), 47-67.

Boyd, J. H., \& De Nicolo, G. (2005). The theory of bank risk taking and competition revisited. The Journal of finance, 60(3), 1329-1343.

Carletti, E., \& Vives, X. (2007, November). Regulation and competition policy in the banking sector. In Prepared for the IESE Business School Conference "Fifty years of the Treaty: Assessment and Perspectives of Competition Policy in Europe," November (pp. 19-20).

Cetorelli, N., \& Gambera, M. (2001). Banking market structure, financial dependence and growth: International evidence from industry data. The Journal of Finance, 56(2), 617-648.

Claessens, S., \& Horen, N. (2014). Foreign banks: Trends and impact. Journal of Money, Credit and Banking, 46(s1), 295-326.

Claessens, S., \& Laeven, L. (2004). What drives bank competition? Some international evidence. Journal of Money, Credit and Banking, 563-583.

Dick, A. A., \& Lehnert, A. (2010). Personal bankruptcy and credit market competition. The Journal of Finance, 65(2), 655-686.

Dell'Ariccia, G., \& Marquez, R. (2006). Lending booms and lending standards. The Journal of Finance, 61(5), 2511-2546.

Demirgüç-Kunt, A., \& Huizinga, H. (2010). Bank activity and funding strategies: The impact on risk and returns. Journal of Financial Economics, 98(3), 626-650.

Demirgüç-Kunt, A., Karacaovali, B., \& Laeven, L. (2005). Deposit insurance around the world: a comprehensive database. World Bank Policy Research Working Paper, (3628).

Dick, A. A., \& Lehnert, A. (2010). Personal bankruptcy and credit market competition. The Journal of Finance, 65(2), 655-686.

Filosa, R. (2007). Stress testing of the stability of the Italian banking system: a VAR approach. Heterogeneity and monetary policy, 703(1), 1-46.

Gan, J. (2004). Banking market structure and financial stability: Evidence from the Texas real estate crisis in the 1980s. Journal of Financial Economics, 73(3), 567-601.

Houston, J. F., Lin, C., Lin, P., \& Ma, Y. (2010). Creditor rights, information sharing, and bank risk taking. Journal of Financial Economics, 96(3), 485-512.

Kallberg, J. G., \& Udell, G. F. (2003). The value of private sector business credit information sharing: The US case. Journal of Banking \& Finance, 27(3), 449-469.

Kothari, C. R. (2004). Research methodology: methods and techniques. New Age International.

Laeven, L., \& Valencia, F. (2010). Resolution of banking crises: The good, the bad, and the ugly. International Monetary Fund.

Marcus, A. J. (1984). Deregulation and bank financial policy. Journal of Banking \& Finance, 8(4), 557-565.

Martinez-Miera, D., \& Repullo, R. (2010). Does competition reduce the risk of bank failure?. Review of Financial Studies, 23(10), 3638-3664.

Niresh, J. A. (2012). Capital structure and profitability in Srilankan banks. Global Journal of management and business research, 12(13).

Padilla, A. J., \& Pagano, M. (2000). Sharing default information as a borrower discipline device. European Economic Review, 44(10), 1951-1980.

Pagano, M., Jappelli, T. (1993). Information sharing in credit markets. Journal of Finance, 48 (5), $1693-1718$.

Pereira, J. P., \& Zhang, H. H. (2010). Stock returns and the volatility of liquidity. Journal of Financial and Quantitative Analysis, 45(2), 1077-1110.

Rajan, R. G., \& Zingales, L. (1995). What do we know about capital structure? Some evidence from international data. The journal of Finance, 50(5), 1421-1460.

Rice, T., \& Strahan, P. E. (2010). Does credit competition affect small-firm finance?. The Journal of Finance, 65(3), 861-889.

Roden, D. M., \& Lewellen, W. G. (1995). Corporate capital structure decisions: evidence from leveraged buyouts. Financial Management, 24, 76-87. 
Tan, H. P., Plowman, D., \& Hancock, P. (2007). Intellectual capital and financial returns of companies. Journal of Intellectual capital, 8(1), 76-95.

Turk Ariss, R. (2010). On the implications of market power in banking: Evidence from developing countries. Journal of Banking \& Finance, 34(4), 765-775.

Wagner, W. (2010). Loan market competition and bank risk-taking. Journal of Financial Services Research, 37(1), 71-81.

Yeh, C. C., Huang, H. C. R., \& Lin, P. C. (2013). Financial structure on growth and volatility. Economic Modelling, 35, 391-400. 